Available online on 15.12.2019 at http://jddtonline.info
Open Access to Pharmaceutical and Medical Research
unrestricted non-commercial use, provided the original work is properly cited

Open $\odot$ Access

Research Article

\title{
Development and Validation of Spectrophotometric and Chromatographic Method for the Estimation of Apremilast in Bulk and Formulations
}

\author{
Pallavi Badhe ${ }^{* 1}$, Smita Aher ${ }^{2}$, Ravindranath B. Saudagar ${ }^{2}$ \\ ${ }^{1}$ Department of Quality Assurance Techniques, KCT’S R.G. Sapkal College of Pharmacy Anjaneri, Nashik, India \\ 2 Department of Pharmaceutical Chemistry, KCT’S R.G. Sapkal College of Pharmacy Anjaneri, Nashik, India
}

\begin{abstract}
Objective: Objective of the present analytical research work was to develop and validate Spectrophotometric method and High Performance Liquid Chromatographic method (HPLC Method) for the Apremilast bulk and tablets dosage form.

Methods: A spectrophotometric method and a HPLC method have been developed and validated for estimation of APR in pharmaceutical oral dosage form.

Method A (UV SPECTROMETRY Method): The stock and working standard solutions of the drugs were prepared in methanol. Standard solutions were scanned over the range of 400-200 $\mathrm{nm}$ in spectrum mode of spectrophotometer at medium scanning speed using UV spectrophotometer. The maximum absorbance for Apremilast was found at $230 \mathrm{~nm}$.

Method B (HPLC Method): The HPLC Method for Apremilast was developed using Cosmosil C18 (4.6mm x 250mm, Particle size: $5 \mu \mathrm{m}$ ), as stationary particle, isocratic mode. Methanol: Water $(80: 20 \mathrm{v} / \mathrm{v}) \mathrm{pH} 3$ as mobile phase. Mobile phase was maintained at a flow rate of 0.8 $\mathrm{ml} / \mathrm{min}$ and detection was carried out at $230 \mathrm{~nm}$. Both the methods were validated in accordance with ICH guidelines

Results: Apremilast was found to be linear in the concentration range of 2-10 $\mu \mathrm{g} / \mathrm{ml}$ for spectrophotometric method and $10-50 \mu \mathrm{g} / \mathrm{ml}$ for HPLC method. Retention time was found to be $4.0 \mathrm{~min}$ for Apremilast. The amount of Apremilast in marketed formulation by spectrophotometric method was found to be $99.82 \%$, the amount of Apremilast in marketed formulation by HPLC method was found to be $99.98 \%$.
\end{abstract}

Interpretation and Conclusion: Results of assay and validation study were found to be satisfactory. So, the methods can be successfully applied for the routine analysis of Apremilast.

Keywords: HPLC, bulk dosage form, tablets,

Article Info: Received 10 Oct 2019; Review Completed 21 Nov 2019; $\quad$ Accepted 29 Nov 2019; Available online 15 Dec 2019

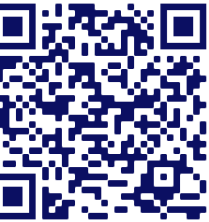

Cite this article as:

Badhe P, Aher S, Saudagar RB, Development and Validation of Spectrophotometric and Chromatographic Method for the Estimation of Apremilast in Bulk and Formulations, Journal of Drug Delivery and Therapeutics. 2019; 9(6-s):136-142 http://dx.doi.org/10.22270/jddt.v9i6-s.3777

*Address for Correspondence:

Pallavi Badhe, Department of Quality Assurance Techniques, KCT’S R.G. Sapkal College of Pharmacy Anjaneri, Nashik, India

\section{INTRODUCTION}

According to recent study no treatment can cure psoriasis but Apremilast can control signs and symptoms of psoriasis. Apremilast is a class of phosphodiester-4 inhibitor used in treatment of rheumatic arthritis and psoriatic arthritis. It is act as an anti-inflammatory caused by these conditions. Phosphodiesterase inhibitor is a cyclic adenosine monophosphate which is predominantly located in inflammatory cells and by inhibiting PDE-4 it increases intracellular level of cAMP which further inhibits proinflammatory mediators including interleukin-2, interferon gamma, TNF-alpha, PDE-4.<smiles>CCOc1cc([C@H](CS(C)(=O)=O)N2C(=O)c3cccc(NC(C)=O)c3C2=O)ccc1OC</smiles>

Figure 1: Structure of Apremilast 
By chemically Apremilast is $\mathrm{N}-[2-[(1 \mathrm{~S})-1-(3-e t h o x y-4-$ methoxyphenyl)-2-(methylsulfonyl)ethyl]-2,3-dihydro-1,3dioxo-1H-isoindol-4-yl]acetamide with molecular formula and weight of C22H24N207S and $460.5 \mathrm{~g} / \mathrm{mole}$ respectively. This analysis method follows ICH validation guidelines. This current research tries to develop new rapid, effective method for determination of Apremilast in bulk form according to ICH Q2 R1 guidelines.

\section{MATERIALS AND METHODS}

\section{Chemicals and Reagents}

Analytically pure samples of Apremilast were kindly supplied by Hetero Drugs Limited., Water (HPLC Grade) and $\mathrm{MeOH}$ (AR grade) Merck specialities private limited, Mumbai

\section{Instrument Used}

Electronic Weighing Balance (Shimadzu AY-220), Ultrasonicator (Wenser pvt ltd PGB-100), Cellulose Acetate Filter, $0.45 \mu \mathrm{m}$ (Nylon 66), HPLC System (Analytical Technologies),UV VIS Spectrophotometer (Shimadzu UV1800)

\section{Spectrophotometric Method}

\subsection{Development of Spectrophotometric Method}

\section{Selection of Solvent}

Solutions of APR $(1000 \mu \mathrm{g} / \mathrm{ml})$ was prepared in different solvents like methanol and water. These solutions were scanned in UV-Visible Region (200 nm to $800 \mathrm{~nm}$ ) and intensity of absorption and wavelength of absorption were studied.

\section{Preparation of Standard Stock Solution}

Standard stock solution was prepared.

\section{Selection of Wavelength Range}

From the stock solutions, $0.1 \mathrm{ml}$ of APR was transferred to 10 $\mathrm{ml}$ volumetric flask and the volume was adjusted to the mark with $\mathrm{MeOH}$ to obtain Strength $10 \mu \mathrm{g} / \mathrm{ml}$. The solution was scanned in the UV range $200-400 \mathrm{~nm}$.

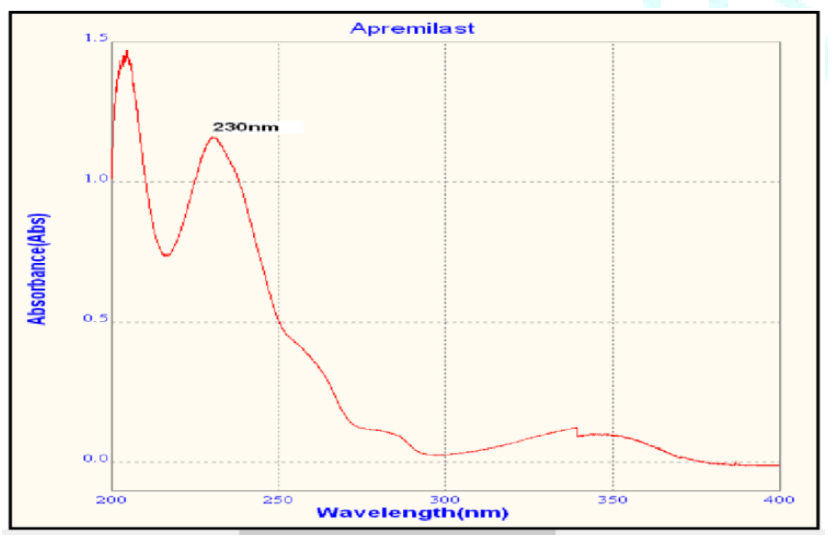

Fig 2. UV spectra of Apremilast

\section{Preparation for Calibration Curve}

Calibration curve were prepared and graph was plotted.

\section{Analysis of Tablets}

For analysis of commercial formulation, twenty tablets were weighed, average weight determined and crushed into fine powder. An accurately weighed quantity of powder equivalent to $10 \mathrm{mg}$ of APR was transferred into $10 \mathrm{ml}$ volumetric flask containing $5 \mathrm{ml}$ methanol, shaken manually for $10 \mathrm{~min}$, volume was adjusted to mark with same solvent and filtered through Whatman filter paper. The absorbance of sample solution was recorded at recorded at $230 \mathrm{~nm}$.

\subsection{Validation of Spectrophotometric Method}

\section{Linearity and Range}

The linearity of analytical method for APR was determined by studying standard calibration curves. The range of analytical method was decided from the interval between upper and lower level of calibration curves by plotting the log curve.

\section{Accuracy}

Accuracy of the method was assessed by standard addition method at three different concentration levels i.e. 50\%, 100,150 . Standard concentration of 2,4 , and $6 \mu \mathrm{g} / \mathrm{ml}$ was added into $4 \mu \mathrm{g} / \mathrm{ml}$ of tablet concentration. The $\%$ recovery was then calculated by using formula

$$
\% \text { Recovery }=\mathrm{A}-\mathrm{B} / \mathrm{C} \text {, }
$$

Where,

$A=$ Total amount of drug estimated

$\mathrm{B}=$ Amount of drug found on pre analysed basis

$\mathrm{C}=$ Amount of Pure drug added

\section{Precision}

The precision of an analytical method was studied by performing intermediate precision.

\section{Intra-day Precision}

Intra-day precision was determined by analyzing the 2,4,6 $\mu \mathrm{g} / \mathrm{ml}$ of APR for three times in the same day.

\section{Inter-day Precision}

Inter-day precision was determined by measuring the the $2,4,6 \mu \mathrm{g} / \mathrm{ml}$ of APR for three consecutive days.

\section{Limit of Detection (LOD) and Limit of Quantitation (LOQ)}

Detection limit and quantitation limit were determined based on the standard deviation of $y$ intercepts of calibration curves and average slope of calibration curves.

$$
\begin{aligned}
& \text { LOD }=3.3 \times \frac{\text { Standard deviation of intercept }}{\text { Slope }} \\
& \text { LOD }=10 \times \frac{\text { Standard deviation of intercept }}{\text { Slope }}
\end{aligned}
$$

\section{Ruggedness}

Ruggedness of the method was checked by two different analysts keeping same experimental and environmental conditions. An appropriate concentration $4,8 \mu \mathrm{g} / \mathrm{ml}$ of APR was subjected to analysis and concentration was determined. This procedure was repeated three times.

\section{Chromatographic Method}

\subsection{Development of Chromatographic method}

\section{Description}

The sample of Apremilast was observed for its color and texture.

\section{Solubility}

The sample of Apremilast was taken in test tubes and observed for solubility in various solvents like alcohol and water. 


\section{Selection of Mobile Phase}

The selection was made on the basis of literature survey. After assessing the solubility of drug in different solvents as well on the basis of literature survey, Methanol and water were selected as a first choice.

\section{Selection of Analytical Wavelength}

To investigate the appropriate wavelength for determination of APR, the solution of the same in the $\mathrm{MeOH}$ were scanned separately by UV-Visible spectrophotometer in the range of 190-400 $\mathrm{nm}$ and the spectrum were recorded.

\section{Preparation of Mobile Phase}

Mobile Phase A: HPLC grade $\mathrm{MeOH}$ was degassed in sonicator for $15 \mathrm{~min}$.

\section{Mobile Phase B: HPLV grade water}

\section{Preparation of Standard Stock Solution}

Standard stock solution was prepared by dissolving $10 \mathrm{mg}$ of Apremilast in $10 \mathrm{ml}$ methanol that gives concentration of $1000 \mathrm{~g} / \mathrm{ml}$ of Apremilast and labeled as Standard stock Apremilast.

\section{Preparation of Calibration Curve}

\section{Analysis of tablets}

To determine the content of APR in conventional tablets; the twenty tablets were weighed, their mean weight determined and they were finely powered and powder equivalent $10.0 \mathrm{mg}$ APR was transferred into a $10 \mathrm{~mL}$ volumetric flask containing $5 \mathrm{~mL}$ methanol, sonicated for 30 min and diluted to $1000 \mathrm{~mL}$ with methanol. The resulting solution was filtered, using $0.22 \mu \mathrm{m}$ filter and $30 \mu \mathrm{g} / \mathrm{mL}$ was injected into system. The amount of APR was determined. The assay procedure was repeated for six times and Calculated using following equation.

$$
\mathrm{Ct}=\underline{\mathrm{Rt} \times \mathrm{Cs}}
$$

Rs

Where, $\mathrm{Ct}$ and $\mathrm{Cs}=$ Concentration of Sample and Standard Solution, respectively. Rt and Rs $=$ Peak Area for Sample and Standard Solution, respectively.

\subsection{Validation of HPLC Method}

\section{Linearity}

The linearity of analytical method for APR was determined by studying standard calibration curves. The range of analytical method was decided from the interval between upper and lower level of calibration curves by plotting the log curve.

\section{Accuracy}

Accuracy of the method was assessed by standard addition method at three different concentration levels i.e. 50\%, $100,150 \%$. Standard concentration of 10,20 and $30 \mu \mathrm{g} / \mathrm{ml}$ was added into $20 \mu \mathrm{g} / \mathrm{ml}$ of tablet concentration. The \% Recoveries was calculated by applying regression equation.

\section{Precision}

The precision of an analytical method was studied by performing intermediate precision.

\section{Intra-day Precision}

Intra-day precision was determined by analyzing the standard solutions of APR $(10,30,50 \mu \mathrm{g} / \mathrm{ml})$ and at three different time intervals on same day.

\section{Inter-day Precision}

Inter-day precision was determined by analyzing the combined standard solution of Apremilast $(10,30,50 \mu \mathrm{g} / \mathrm{ml})$ on three consecutive days. The results were reported in terms of \% RSD.

\section{Limit of Detection and Limit of Quantitation}

Detection limit and quantitation limit were determined based on the standard deviation of $y$ intercepts of calibration curves and average slope of calibration curves.

$$
\begin{aligned}
& \text { LOD }=3.3 \times \frac{\text { Standard deviation of intercept }}{\text { Slope }} \\
& \text { LOD }=10 \times \frac{\text { Standard deviation of intercept }}{\text { Slope }}
\end{aligned}
$$

\section{Robustness}

Standard solution of APR $(30 \mu \mathrm{g} / \mathrm{ml}))$ were used and analyzed at different flow rate $(0.7,0.8,0.9 \mathrm{ml} / \mathrm{min})$ and wavelength $(228,230,232 \mathrm{~nm})$.

\section{Ruggedness}

Ruggedness of the method was checked by two different analysts keeping same experimental and environmental conditions. An appropriate concentration $30 \mu \mathrm{g} / \mathrm{ml}$ of APR was subjected to analysis and concentration was determined. This procedure was repeated three times.

\section{System Suitability}

Standard solution of APR $(30 \mu \mathrm{g} / \mathrm{ml})$ was prepared and analyzed. Chromatograms were studied for different parameters such as tailing factor, resolution and theoretical plates to see that whether they complies with the recommended limit or not.

\section{RESULT AND DISCUSSION}

\section{UV-Visible Spectrophotometric Methods}

\section{Linearity study}

Standard solution having concentration range of 2,4,6,8,10 $\mu \mathrm{g} / \mathrm{ml}$ of APR was prepared. Absorbances of these solutions were recorded at $230 \mathrm{~nm}$. Calibration curve was plotted, absorbance vs concentration. Fig3,Table 1.

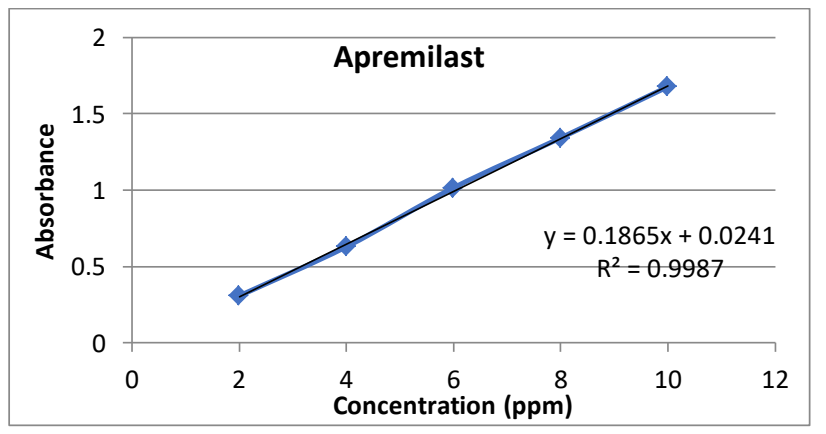

Fig 3. Calibration curve by UV

Table 1. Data of calibration curve by UV

\begin{tabular}{|c|c|c|}
\hline Sr. No. & Conc. $(\boldsymbol{\mu g} / \mathbf{m L})$ & Absorbance \\
\hline 1 & 2 & 0.4069 \\
\hline 2 & 4 & 0.7786 \\
\hline 3 & 6 & 1.1225 \\
\hline 4 & 8 & 1.4916 \\
\hline 5 & 10 & 1.9151 \\
\hline
\end{tabular}


Table 2. linear regression analysis by UV

\begin{tabular}{|c|c|c|}
\hline Sr.No & Parameters & Zero Order spectrophotometric method \\
\hline $\mathbf{1}$ & $\lambda \max (\mathrm{nm})$ & 230 \\
\hline $\mathbf{2}$ & Beer's law limit $(\mu \mathrm{g} / \mathrm{mL})$ & $2-10$ \\
\hline $\mathbf{3}$ & Regression equation $[\mathrm{y}]$ & $\mathrm{y}=0.1865 \mathrm{x}+0.0241$ \\
\hline $\mathbf{4}$ & Slope[m] & 0.1865 \\
\hline $\mathbf{5}$ & Intercept $[\mathrm{c}]$ & 0.0241 \\
\hline $\mathbf{6}$ & Correlation coefficient $[\mathrm{r} 2]$ & 0.9987 \\
\hline $\mathbf{7}$ & Limit of detection $(\mathrm{LOD})(\mu \mathrm{g} / \mathrm{mL})$ & 0.0424 \\
\hline $\mathbf{8}$ & Limit of quantitation $(\mathrm{LOQ})(\mu \mathrm{g} / \mathrm{mL})$ & 0.1286 \\
\hline
\end{tabular}

\section{Assay of Marketed Formulation}

Using this method, the marketed formulation was analyzed. Sample solution containing $6 \mu \mathrm{g} / \mathrm{ml}$. The amount of drug present in the marketed formulation was calculated .The mean \% assay of APR was found to be $99.82 \%$. Table 3 .

Table 3. Result of tablet analysis

\begin{tabular}{|c|c|c|c|}
\hline Drug Name & Mean* & SD & \%RSD \\
\hline Otezla & 99.82 & 1.0586 & 1.06 \\
\hline
\end{tabular}

\section{Validation Parameters}

Validation of the method was performed in accordance to ICH guidelines. Accuracy of the method was determined at $50 \%, 100 \%$ and $150 \%$ level by standard addition method and percentage recovery APR were found to be in the range of $99.93-100.29 \%$. Precision of the method was determined by \% RSD of intra-day precision, inter-day precision. It was found to be less LOD and LOQ of APR was found to be 0.0424 and $0.1286 \mu \mathrm{g} / \mathrm{ml}$, respectively.

Table 4. Result of Accuracy study

\begin{tabular}{|c|c|c|c|}
\hline Level of addition & \% Mean recovery* & SD & \% RSD \\
\hline $50 \%$ & 100.22 & 0.2553 & 0.25 \\
\hline $100 \%$ & 100.29 & 0.1931 & 0.19 \\
\hline $150 \%$ & 99.93 & 0.1154 & 0.11 \\
\hline
\end{tabular}

Table 5A. Result of intraday precision

\begin{tabular}{|c|c|c|c|c|c|}
\hline Sr.No & Conc. $(\boldsymbol{\mu g} / \mathbf{m L})$ & Absorbance & Mean & SD & \%RSD \\
\hline 1 & 2 & 0.4051 & & \multirow{2}{*}{0.74} \\
\hline 2 & 2 & 0.4069 & & \multirow{2}{*}{0.0030} & \\
\hline 3 & 2 & 0.4010 & & \multirow{2}{*}{0.7759} & \multirow{2}{*}{0.0032} \\
\hline 4 & 4 & 0.7769 & & \\
\hline 5 & 4 & 0.7786 & & \multirow{2}{*}{0.0039} & \multirow{2}{*}{0.34} \\
\hline 7 & 6 & 0.7723 & & & \\
\hline 8 & 6 & 1.1236 & & & \\
\hline
\end{tabular}

Table 5B. Result of interday precision

\begin{tabular}{|c|c|c|c|c|c|}
\hline Sr.No & Conc. $(\mu \mathrm{g} / \mathrm{mL})$ & Absorbance & Mean & SD & \%RSD \\
\hline 1 & 2 & 0.4036 & & \multirow{3}{*}{0.0031} & \multirow{3}{*}{0.76} \\
\hline 2 & 2 & 0.4069 & & & \\
\hline 3 & 2 & 0.4098 & & & \\
\hline 4 & 4 & 0.7726 & \multirow{3}{*}{0.7758} & \multirow{3}{*}{0.0030} & \multirow{3}{*}{0.39} \\
\hline 5 & 4 & 0.7786 & & & \\
\hline 6 & 4 & 0.7763 & & & \\
\hline 7 & 6 & 1.1253 & \multirow{3}{*}{1.1239} & \multirow{3}{*}{0.0014} & \multirow{3}{*}{0.12} \\
\hline 8 & 6 & 1.1225 & & & \\
\hline 9 & 6 & 1.1241 & & & \\
\hline
\end{tabular}


Table 6A. result of robustness study

\begin{tabular}{|c|c|c|c|c|}
\hline \multirow{2}{*}{ Parameters } & \multicolumn{3}{|c|}{ Change In Wavelength( $\pm 2 \mathbf{~ n m})$} \\
\cline { 2 - 5 } & \multicolumn{2}{|c|}{ Wavelength (228nm) } & Wavelength (232nm) \\
\hline & $\mathbf{4 ~ p p m}$ & $\mathbf{8} \mathbf{~ p p m}$ & $\mathbf{4} \mathbf{~ p p m}$ & $\mathbf{8} \mathbf{~ p p m}$ \\
\hline Mean(n=3) & 0.7761 & 1.4908 & 0.7774 & 1.4902 \\
\hline SD & 0.0007 & 0.0006 & 0.0001 & 0.0016 \\
\hline \% RSD & 0.1917 & 0.0988 & 0.4818 & 0.2634 \\
\hline
\end{tabular}

Table 6B. result of robustness study

\begin{tabular}{|c|c|c|c|c|}
\hline \multirow{3}{*}{ Parameters } & \multicolumn{4}{|c|}{ Change In Solvent } \\
\hline & \multicolumn{2}{|c|}{ Water } & \multicolumn{2}{|c|}{$0.1 \mathrm{~N} \mathrm{NaOH}$} \\
\hline & 4 ppm & $8 \mathrm{ppm}$ & $4 \mathrm{ppm}$ & $8 \mathrm{ppm}$ \\
\hline Mean(n=3) & 0.7765 & 1.4910 & 0.7763 & 1.4895 \\
\hline SD & 0.00079 & 0.0015 & 0.0006 & 0.0008 \\
\hline \% RSD & 0.250 & 0.3614 & 0.2086 & 0.2091 \\
\hline
\end{tabular}

Table 7. result of ruggedness study

\begin{tabular}{|c|c|c|c|c|}
\hline \multirow{3}{*}{ Parameters } & \multicolumn{4}{|c|}{ Change in Analyst } \\
\hline & \multicolumn{2}{|c|}{ Analyst I } & \multicolumn{2}{|c|}{ Analyst II } \\
\hline & 4ppm & 8ppm & 4ppm & 8ppm \\
\hline Mean(n=3) & 0.7784 & 1.4932 & 0.7769 & 1.4920 \\
\hline SD & 0.0006 & 0.0008 & 0.0011 & 0.0006 \\
\hline \% RSD & 0.2807 & 0.2076 & 0.5467 & 0.1460 \\
\hline
\end{tabular}

\section{Chromatographic Method}

\section{Selection of Analytical Wavelength}

The standard solutions of APR $(10 \mu \mathrm{g} / \mathrm{ml})$ in mobile phase were scanned in the UV region of $190-400 \mathrm{~nm}$ and the overlain spectra were recorded. It was observed that APR drugs showed the absorbance at $230 \mathrm{~nm}$. So, the wavelength of detection used was $230 \mathrm{~nm}$.

\begin{tabular}{|c|c|}
\hline Mobile phase & $\begin{array}{c}\text { Methanol : Water }(80: 20 \mathrm{v} / \mathrm{v}) \\
\mathrm{pH} 3\end{array}$ \\
\hline Selection of column & $\begin{array}{c}\text { Cosmosil C18 }(4.6 \mathrm{~mm} \times 250 \mathrm{~mm}, \\
\text { Particle size: } 5 \mu \mathrm{m})\end{array}$ \\
\hline Injection volume & $20 \mu \mathrm{L}$ \\
\hline Flow rate & $0.8 \mathrm{ml} / \mathrm{min}$ \\
\hline Column temperature & Room Temperature \\
\hline $\begin{array}{c}\text { Detection } \\
\text { wavelength }\end{array}$ & $230 \mathrm{~nm}$ \\
\hline Retention time & $4.0 \mathrm{~min}$ \\
\hline
\end{tabular}

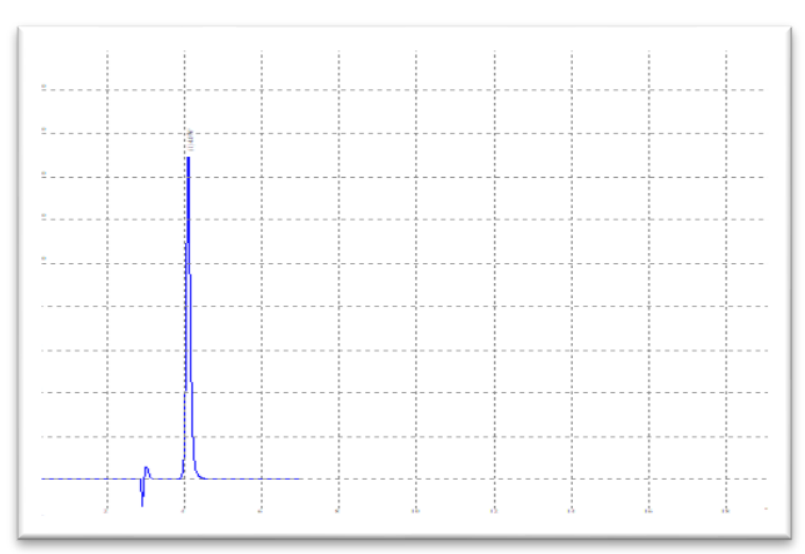

Figure 4. Typical chromatograph of Apremilast by HPLC at Optimized condition

\section{Linearity Study}

APR was found to be linear in the concentration range of 10$50 \mu \mathrm{g} / \mathrm{ml}$. Fig 5, Table 8 and Table 9

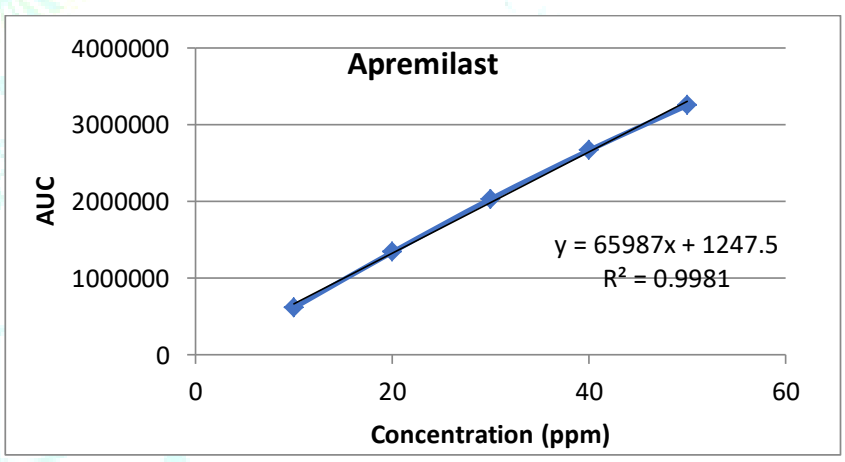

Fig 5. calibration curve by HPLC

Table 8. Result of calibration curve

\begin{tabular}{|c|c|c|}
\hline Sr. No. & Conc. $(\boldsymbol{\mu g} / \mathbf{m l})$ & Area \\
\hline 1 & 10 & 614839 \\
\hline 2 & 20 & 1339880 \\
\hline 3 & 30 & 2032564 \\
\hline 4 & 40 & 2665713 \\
\hline 5 & 50 & 3251263 \\
\hline
\end{tabular}

Table 9. Linear regression analysis

\begin{tabular}{|c|c|c|}
\hline S.N. & Parameters & HPLC method \\
\hline $\mathbf{1}$ & $\lambda \max (\mathrm{nm})$ & 230 \\
\hline $\mathbf{2}$ & Beer's law limit $(\mu \mathrm{g} / \mathrm{mL})$ & $10-50$ \\
\hline $\mathbf{3}$ & Regression equation[y] & $\mathrm{y}=65987 \mathrm{x}+1247.5$ \\
\hline $\mathbf{4}$ & Slope $[\mathrm{m}]$ & 65987 \\
\hline $\mathbf{5}$ & Intercept $[\mathrm{c}]$ & 1247.5 \\
\hline $\mathbf{6}$ & Correlation coefficient [r2 ] & 0.9981 \\
\hline $\mathbf{7}$ & Limit of detection (LOD) & 0.1646 \\
\hline $\mathbf{8}$ & Limit of quantitation (LOQ) & 0.4988 \\
\hline
\end{tabular}




\section{Assay of Marketed Formulation}

Amount of drugs present in the marketed formulation equations. Amount of APR found in the range from $99.99 \%$ and $\mathrm{SD} \pm 0.015$. Table 10

Table 10. Assay result by HPLC

\begin{tabular}{|c|c|c|c|}
\hline Drug Name & Mean* & SD & \%RSD \\
\hline Otezla & 99.98 & 0.0605 & 0.06 \\
\hline
\end{tabular}

\section{Validation Parameters}

This method was validated in accordance to ICH guidelines. Percentage of recoveries of APR was found in the range from $98.65-101.69 \%$. Precision of the method was determined by \% RSD found among intra-day precision, inter-day precision. LOD and LOQ of APR were found to be 0.1646 and $0.4988 \mu \mathrm{g} / \mathrm{ml}$, respectively. For robustness study, the effect of change in wavelength and flow rate ( \pm 0.1 $\mathrm{ml} / \mathrm{min}$ ) on the Mean peak area, \% RSD and \% Assay were studied. Percentage RSD of each peak in all variables was found to be less than $2 \%$. Table 11,12A,12B,13,14,15.

Table 11. Result of Accuracy by HPLC

\begin{tabular}{|c|c|c|c|}
\hline Level of addition & \% Mean recovery* & SD & \% RSD \\
\hline $50 \%$ & 99.99 & 0.1795 & 0.17 \\
\hline $100 \%$ & 100.06 & 0.3547 & 0.35 \\
\hline $150 \%$ & 100.07 & 0.1026 & 0.10 \\
\hline
\end{tabular}

Table 12A. Result of intraday precision

\begin{tabular}{|c|c|c|c|c|c|}
\hline Sr. No. & Conc. $(\mu \mathrm{g} / \mathrm{mL})$ & Area & Mean & SD & \%RSD \\
\hline 1 & 10 & 614839 & \multirow{3}{*}{615216} & \multirow{3}{*}{525.86} & \multirow{3}{*}{0.08} \\
\hline 2 & 10 & 615817 & & & \\
\hline 3 & 10 & 614993 & & & \\
\hline 4 & 30 & 2032564 & \multirow{3}{*}{2033124} & \multirow{3}{*}{3313.68} & \multirow{3}{*}{0.16} \\
\hline 5 & 30 & 2030126 & & & \\
\hline 6 & 30 & 2036682 & & & \\
\hline 7 & 50 & 3251263 & \multirow{3}{*}{3252790} & \multirow{3}{*}{3500.16} & \multirow{3}{*}{0.10} \\
\hline 8 & 50 & 3256795 & & & \\
\hline 9 & 50 & 3250314 & & & \\
\hline
\end{tabular}

Table 12B Result of Interday precision

\begin{tabular}{|c|c|c|c|c|c|}
\hline Sr. No. & Conc. $(\boldsymbol{\mu g} / \mathbf{m L})$ & Area & Mean & SD & \%RSD \\
\hline 1 & 10 & 614839 & \multirow{2}{*}{614901} & \multirow{2}{*}{1283.14} & \multirow{2}{*}{0.20} \\
\hline 2 & 10 & 613651 & & \\
\hline 3 & 10 & 616215 & & \multirow{2}{*}{0.16} \\
\hline 4 & 30 & 2032564 & \multirow{2}{*}{2034800} & & \multirow{2}{*}{0.07} \\
\hline 6 & 30 & 2033215 & & \\
\hline 7 & 50 & 2038621 & & \multirow{2}{*}{2445.83} & \\
\hline 9 & 50 & 3253512 & & & \\
\hline
\end{tabular}

Table 13. Result of robustness study

\begin{tabular}{|c|c|c|c|c|c|c|}
\hline Sr.No & Parameter & Condition & Area & Mean & SD & \%RSD \\
\hline 1 & & 0.7 & 1333913 & \multirow{3}{*}{1337183} & \multirow{3}{*}{3024.58} & \multirow{3}{*}{0.22} \\
\hline 2 & & 0.8 & 1339880 & & & \\
\hline 3 & & 1.0 & 1337757 & & & \\
\hline 1 & \multirow{3}{*}{ Change in Wavelength } & 228 & 1340385 & \multirow{3}{*}{1340629} & \multirow{3}{*}{896.26} & \multirow{3}{*}{0.06} \\
\hline 2 & & 230 & 1339880 & & & \\
\hline 3 & & 232 & 1341622 & & & \\
\hline
\end{tabular}

Table 14. Result of Ruggedness

\begin{tabular}{|c|c|c|c|c|c|}
\hline Sr.No & Analyst & Conc. $(\boldsymbol{\mu g} / \mathbf{m l})$ & Mean area $^{*}$ & SD & \% RSD \\
\hline $\mathbf{1}$ & Analyst-I & 30 & 2033124 & 3313.68 & 0.16 \\
\hline $\mathbf{2}$ & Analyst-II & 30 & 2035415 & 1083.08 & 0.05 \\
\hline
\end{tabular}


Table 15. Result of system Suitability

\begin{tabular}{|c|c|c|c|c|}
\hline Sr. No. & conc. $(\boldsymbol{\mu g} / \mathbf{m l})$ & $\begin{array}{c}\text { Retention } \\
\text { Time } / \mathbf{m i n}\end{array}$ & Theoretical plates & Asymmetry Factor \\
\hline 1 & 30 & 4.0 & 8988 & 1.25 \\
\hline 2 & 30 & 4.0 & 8897 & 1.25 \\
\hline 3 & 30 & 4.0 & 8709 & 1.25 \\
\hline 4 & 30 & 4.0 & 8685 & 1.25 \\
\hline 5 & 30 & 4.0 & 8479 & 1.24 \\
\hline 6 & 30 & 4.0 & 8900 & 1.24 \\
\hline Mean & & 4.00 & 8859.66 & 1.246 \\
\hline SD & & 0.00 & 131.86 & 0.0051 \\
\hline \%RSD & & 0.00 & 1.48 & 0.41 \\
\cline { 3 - 5 } & & & & \\
\hline
\end{tabular}

\section{CONCLUSION}

In the present investigation, the developed and validated, UV Spectrophotometric method were found to be simple, economical and rapid method. HPLC was found to more precise, accurate, rugged and robust for determination of Apremilast. The excipients usually present in the pharmaceutical formulation did not interfere with determination of Apremilast. Developed method can be successfully used in laboratory to measure the concentration of API in specific dosage form. This method is also beneficial for the formulation and development department. These methods are always useful for analysis, purity testing and assay. The consumption of time and chemicals is less as compare to other tedious method. This is new concept for the validation of method development and method transfer in pharmaceutical companies. The results and the statistical parameters demonstrate that the proposed UV spectrophotometric and HPLC method is simple, rapid, specific, accurate and precise.

\section{ACKNOWLEDGEMENT}

Authors are thankful to R. G. Sapkal college of Pharmacy for providing necessary requirements. Authors are also thankful to Dr. Ravindranath saudagar sir for their valuable support and guidance.

\section{REFERENCES}

1. ICH, Q2 (R1); Validation of Analytical Procedure: text and methodology. International Conference on Harmonization, Geneva, 2005; 1-13.

2. Beckett $\mathrm{AH}$ and Stenlake JB. Practical Pharmaceutical Chemistry, Part-II, 4th Ed., New Dehli; CBS Publishers and Distributors, 2004; 85- 174.

3. Willard HH, Merrist LL, Dean AJ, Frank A and Settle AF. Instrumental Methods of Analysis, 7th Ed., New Dehli; CBS Publishers and Distributors, 1986; 2-3, 585-587
4. Skoog DA, Holler FJ and Nieman TA. Principle of Instrumental Analysis, 5th Ed., Thomson Publication Limited, London, 2004; 103.

5. Sethi PD., High Performance Liquid Chromatography, Quantitative Analysis of Pharmaceutical Formulations, 1st edition, New Delhi; CBS Publishers and Distributors, 2001; 3$11,116-120$

6. Toomula N, Kumar A, Kumar S, Bheemidi VS. Development and Validation of Analytical Methods for Pharmaceuticals \& Bioanalytical Techniques, 2011; 2(5): 1-4.

7. Lakshmi SRP. A Review on Chromatography with High Performance Liquid Chromatography (HPLC) and its Functions. Research and Reviews: Journal of Pharmaceutical Analysis, March 2015; 4(1):1-15.

8. Swartz ME. HPLC: An introduction and review. J Liq Chromatogr Rel Technol. 2005; 25:1253-63.

9. Panchumarthy R, Shaheem S, Kamma HS, Development and Validation of a Stability-Indicating Reversed Phase Hplc Method for Determination of Apremilast in Bulk and Pharmaceutical Dosage Form, Der Pharmacia Lettre, 2017; 9 [6]:63-73.

10. Lonkar NA, Sawant SD, Dole MN, Development and validation of stability indicating rp-hplc method for estimation of Apremilast by forced degradation studies, wjpps, 6(4):14931502.

11. Rele RV, Patil SP, Reversed Phase High Performance Liquid Chromatography Method for Determination of Assay and Forced Degradation Study of Apremilast from Active Pharmaceutical Dosage Form, Journal of Chemical and Pharmaceutical Research, 2018; 10(7):139-144.

12. Panchumarthy $R$, Sulthana MDS, Srinivasa Babu $P$, Development and validation of stability-indicating UV spectrophotometric method for determination of Apremilast in bulk and pharmaceutical dosage form, Indian Journal of Research in Pharmacy and Biotechnology, 2017; 5(1):47-53.

13. Chakravarthy AV, Sailaja BBV, Praveen KA, method development and validation of uv-visible spectroscopic method for estimation of assay of sugammadex sodium, Apremilast, riociguat and vorapaxar sulfate drugs in active pharmaceutical ingredient form, Asian J Pharm Clin Res, 2017; $10(2): 241-250$. 